\title{
VALIDITY OF COMPUTER-BASED ELECTROLYTE FISHER GAME TO DEVELOP PROBLEM-SOLVING SKILL OF STUDENTS IN ELECTROLYTE AND NONELECTROLYTE SOLUTION
}

\author{
Lukjijatul Lutfiana, and *Rusly Hidayah \\ Chemistry Department Mathematics and Natural Science Faculty Universitas Negeri Surabaya \\ e-mail: $\underline{\text { ruslyhidayah@unesa.ac.id }}$
}

\begin{abstract}
The aim of this research was to get a valid computer-based Electrolyte Fisher game to develop problemsolving skill of students on electrolyte and nonelectrolyte solution topics so it could be used in learning activity. The type of this research was development research by using 4D model with four stages including define, design, develop, and disseminate, but the stages carried out in this research only until development stage. Validity was determined by two chemistry lecturers and one chemistry teacher. Research results proved that Electrolyte Fisher game was valid based on content validity percentage of $84.44 \%$ and construct validity percentage of $85.37 \%$. There were three criteria assessed in content validity including the correctness of concepts in matter obtaining a percentage of $86.67 \%$; the suitability of matter with learning objectives obtaining $86.67 \%$; and the suitability of game with problem-solving skill component obtaining $80.00 \%$. There were two criteria assessed in construct validity, namely the suitability of game with learning media requirements which included nine aspects obtaining percentage of $87.78 \%$ and the suitability of display quality in game which included three aspects obtaining $82.96 \%$. Based on results of this research showed that the computer-based Electrolyte Fisher game to develop students' problem-solving skill was declared valid.
\end{abstract}

Key words: electrolyte fisher game, problem-solving skill, electrolyte, and nonelectrolyte solution.

\section{INTRODUCTION}

Based on the Minister of Education and Culture Regulation Number 22 The Year 2016 perfected by the Minister of Education and Culture Regulation Number 36 The Year 2018 states that the 2013 curriculum was developed with an improved mindset consisting of several learning principles including learning pattern that are student-centered, and one-way learning patterns become interactive learning [1] [2]. One of the teacher's tasks is a facilitator to create an enjoyable learning situation and encourage students to actively participate in learning at the classroom. Chemistry subject is one of the subjects taught in senior high school which is in the 2013 curriculum, chemistry includes specialization subjects in group C. Chemistry subject learn everything about substances regarding composition, properties, changes, dynamics, and energetics related to reasoning and skills [3].

The characteristics of chemistry subject have difficulty levels related to concept abstraction, chemical changes at the atomic level, and the use of symbols. There are three levels of representation used in chemistry learning, namely macroscopic, symbolic, and sub-microscopic. Macroscopic representation of chemical phenomena that can be observed with the human senses. Symbolic representation in the form of signs or language or other forms to express observation results both qualitatively and quantitatively. Sub-microscopic representation is abstract representation of chemical phenomena in the form of concepts, theories, and principle properties from particulate level. Macroscopic and symbolic representations do not represent changes that occur at the atomic or molecular level so submicroscopic representation is needed to describe these changes [4]. One of the topics in chemistry subject that require three representations is electrolyte and nonelectrolyte solution topics.

Learning process on electrolyte and nonelectrolyte solution topics, students are required to identify the type of solution through observation macroscopically, describe the process of ionization sub microscopically and relate it to the conductivity strength of electrolyte solutions symbolically through the reaction equation and degree of ionization. The characteristics of abstract in that matter located in the ionization reaction of 
compounds in solution, so it is needed a media that can manifest concept to be easily understood by students [5]. Some senior high schools use chemistry books that discuss electrolyte solution topics only in short reviews of electrolyte solution properties through experimental observation (macroscopic representation) without discussing the processes that occur in an electrolyte solution so that it can conduct an electric current. But students should understand how the ionization process of molecules in a solvent so that a solution can be classified into the strong electrolyte, or weak electrolyte or nonelectrolyte [6].

Based on the result of the chemistry teacher interview, the teacher had difficulty in visualizing ionization reaction (sub-microscopic representation) in the concept of electrolyte and nonelectrolyte solution so that students did not understand the concept of matter and were more comfortable memorizing the matter. This was also supported by the result of the pre-research questionnaire obtained at Senior High School 3 Surabaya, proven that $69.69 \%$ of students said the matter was quite difficult to learn because of abstract matter. By developing media, it was expected to fulfill the characteristics of electrolyte and nonelectrolyte solution topics in three representations where there are videos explaining the material macroscopically about changes in solution through observation; sub-microscopically about the mechanism of ionization reactions and the process of a solution can conduct electric current; symbolically about chemical formulas and reaction equations.

Learning chemistry through the problemsolving is expected to build understanding concepts of students so that the matter being studied is more meaningful. In this case, students develop knowledge of chemical concepts independently through teacher guidance [7]. Electrolyte and nonelectrolyte solution is one of the topics in chemistry lessons that are closely related in everyday life. Burner states that if students try their own to get problem-solving with the knowledge they have, students will get knowledge and experience that is truly meaningful [8]. This was perfected by Minister of Education and
Culture Regulation Number 61 The Year 2014 which stated that one of the competencies needed in the future was to solve complex problems across scientific sectors [9]. Problem-solving skill is a cognitive process in the form of continuous and gradual activities so that require learning efforts and exercises [10]. Paul Eggen and Don Kauchak divided problem-solving skill into of 4 aspects including (1) identify the problem; (2) formulate hypothesis; (3) collect and analyze data; and (4) evaluate hypothesis and make generalization [11].

The result of the chemistry teacher interview at Senior high school 3 Surabaya revealed that learning on electrolyte and nonelectrolyte solution topics was conducted using the problem-based learning model to develop students' problem-solving skill because the matter was very concerned with the daily life of students. Based on the pre-research result, the percentage of problem-solving skill possessed by students of grade 11 Science 3 by answering questions correctly for (1) identify the problem $15.15 \%$; (2) formulate hypothesis $0 \%$; (3) collect and analyze data 6,06\%; and (4) evaluate hypothesis and make generalization $12,12 \%$. Based on these data, it could be concluded that the problem-solving skill of students was still low so that media was needed to increase problem-solving skill.

Nowadays, the era of industrial revolution 4.0 is underway where everything in human life is already utilizing digital technology, including in the education sector. This allows learning activities carried out in accordance with the learning styles of students. In addition, the use of technology as an interactive learning media can accommodate teachers in encouraging students to actively participate in learning activities. One of the right media to be used as interactive learning media is a game developed based on "fun learning" [12]. The computer game is an effective tool for learning chemical concepts and making learning meaningful because playing the game can support active learning, concentration, and the utilization of trial and error [13]. Playing the game as a learning media is also supported by the frequency of playing games of senior high school students during 21-30 hours per week [14]. 
Based on the pre-research result obtained at Senior High School 3 Surabaya showed that 93.93\% of students expressed pleasure when playing while learning and as much as $75.75 \%$ of students wanted to use the game in chemistry learning activities. $63.63 \%$ of students learned by noting important concepts and $30.30 \%$ of students learned by doing exercises so that in making games presented with the form of exercises and discussion. The game that has been developed on electrolyte and nonelectrolyte solution topics until now, there has not been trained problem-solving skill. This statement is based on field studies of games that are downloaded from Play Store application and search engine. In Tomb Labs Raider game that has been developed by Desiana Anggraeni and Achmad Lutfi had a simulation of solution test (macroscopic and symbolic representation), but there was no sub-microscopic representation of matter (mechanism of ionization reaction and process of a solution can conduct electric current) [15]. In Super Chemistry game that has been developed by Annisa Rahmawati and Achmad Lutfi, there was no visualization of solution test so that matter representation macroscopically and sub-microscopically was not yet available [16].

The newness of game developed in this research was to bring up macroscopic, submiscroscopic, and symbolic representations in the form of videos (matter video and experimental video); and develop problem-solving skill. The use of digital games especially in the form of simulation in learning is very useful in the construction of knowledge and improve students' problem-solving skill [17] [18]. Electrolyte Fisher game contains matter, question exercises, discussions, experimental videos, and missions to arrange experimental tools that are adjusted to the problem skill component. Apart from low problemsolving skill, students are difficult to understand the concept of matter because there is no media that can visualize sub-microscopic representation. Therefore, in this game there are video of matter and experiment which will visualize the mechanism of ionization reaction in solution so that it is expected to overcome the difficulties of students. Based on the description above, needed learning media that could develop problem-solving skill through fun learning. The aim of this research was to get a valid Electrolyte Fisher game to develop problem-solving skill on electrolyte and nonelectrolyte solution topics.

\section{METHOD}

This type of research was development research by adapting the $4 \mathrm{D}$ model developed by Thiagarajan, et al [19]. The 4D development model was divided into four stages namely define, design, develop and disseminate, but the stages carried out in this research only until the develop stage. The steps carried out in this research were illustrated in Figure 1. This research was conducted to develop the Fisher Electrolyte game to develop students' problem-solving skill on electrolyte and nonelectrolyte solution topics. The problemsolving skill components developed in this research was adapted from Paul Eggen and Don Kauchak which included (1) identify the problem; (2) formulate hypothesis; (3) collect and analyze data; and (4) evaluate hypothesis and make generalization [11].

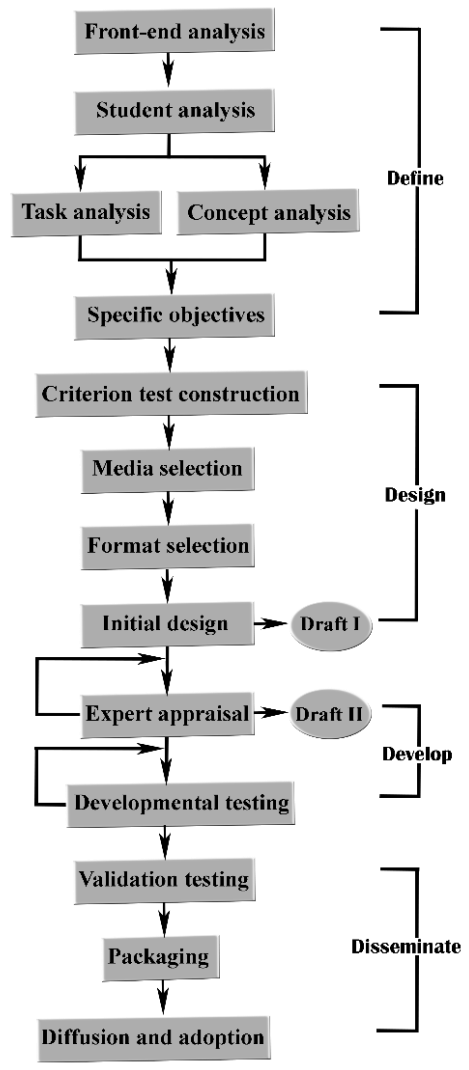

Figure 1. The 4D Development Model [19] 
The data source of this research was obtained from the assessment of chemistry lecturers and chemistry teacher as matter and learning media experts. The research instruments needed were review sheet and validation sheet. The review sheet aimed to get some suggestions from reviewer for the game being developed, while the validation sheet aimed to determine whether the game was valid or not as a learning media in learning activities. The Electrolyte Fisher game was reviewed by a chemistry lecturer by giving suggestion then filling out revisions on the review sheet. After the game was revised according to the result of previous reviews, validation assessment was carried out by two chemistry lecturers of Universitas Negeri Surabaya and one chemistry teacher of Senior High School 1 Puri Mojokerto by filling in the scores on the validation sheet.

The validity of game was assessed based on content validity/relevance and construct validity/consistency [20]. The content validity consisted of three aspects, namely the correctness of concept, the suitability of matter with learning objectives, and the suitability of game with problem-solving skill components. In construct validity, there are twelve aspects assessed covering nine aspects of the suitability of game with learning media requirements and three aspects of the suitability of display quality. The validation data was analyzed with quantitative descriptive that described development research results of Electrolyte Fisher game with a percentage from scores on the validation sheet.

The assessment of game validation used a Likert scale as in the Table 1.

Table 1. Likert Scale of Validity

\begin{tabular}{cc}
\hline Assessment & Score \\
\hline Very Less & 1 \\
Less & 2 \\
Enough & 3 \\
Good & 4 \\
Very Good & 5 \\
\hline
\end{tabular}

Based on the criteria for validity score of the computer-based Electrolyte Fisher game as learning media in Table 1, the percentage of game validity was calculated using the following formula.
$\mathrm{P}(\%)=\frac{\text { The number of score from } 3 \text { validators }}{\text { Criterion score }} \times 100 \%$

with, Criterion score $=$ highest score for each aspect $\mathrm{x}$ number of aspects $\mathrm{x}$ number of validators

Then result of percentage calculation was interpreted into criteria shown in Table 2.

Table 2. Criteria for Interpretation of Validity Percentage

\begin{tabular}{cc}
\hline Percentage (\%) & Category \\
\hline $0-20$ & Not Valid \\
$21-40$ & Less Valid \\
$41-60$ & Valid Enough \\
$61-80$ & Valid \\
$81-100$ & Very valid \\
\hline
\end{tabular}
[21]

Based on the interpretation of percentage criteria, Electrolyte Fisher game was declared valid if it got a percentage $\geq 61 \%$ with a valid category or very valid category.

\section{RESULTS AND DISCUSSION}

Research results and analysis data obtained based on the procedure of $4 \mathrm{D}$ development model were as follows.

\section{Define Stage}

The define stage had aim to determine and define various learning requirements. This define stage consists of five steps including Front-end Analysis, Learner Analysis, Task Analysis, Concept Analysis, and Specifying Instructional Objectives. The front-end analysis included curriculum analysis which aimed to bring up the basic problem used in developing games as learning media. The process of determining the problem was conducted by studying literature and field (conducting observation, interviewing, and distributing questionnaires). The curriculum used by Senior High School 3 Surabaya was 2013 curriculum revised 2018. Based on the pre-research results, students found difficulty to understand electrolyte and nonelectrolyte topics because there was no media to visualize concepts.

Learner analysis was conducted by looking at the characteristics, ability, and experience of students both as individual and group. Learner analysis in the form of age, learning style, 
academic ability, learning motivation, psychomotor skill, and so on. Based on the age of students, the average students are aged 15-16 years. Based on Piaget's theory, the child in that age was in formal operational stage, wherein the child had ability to reason logically, think abstractly, and make conclusion from various information [22]. The result of interview with chemistry teacher showed that the students' academic ability in one class was heterogeneous. Learning style of students referred to textbook, explanation from the teacher, and information from electronic media. The motivation for chemistry subject was high, but there were some students who were still passive. Result of the pre-research showed that the students' problem-solving skill was still low.

The purpose of task analysis was to describe some tasks carried out by students to complete the learning objectives that have been arranged. In this research, the students' task was to operate game and answer questions in game correctly. Concept analysis in the form of identifying some main concepts in the matter, then drafting concepts systematically.

The Specifying Instructional Objectives step was conducted based on the results of task analysis and concept analysis into learning objectives which were then used as a basic in learning activities. The Specifying Instructional Objectives was combined with the problemsolving skill components that were trained covering four aspects including: (1) identify the problem; (2) formulate hypothesis; (3) collect and analyze data; and (4) evaluate hypothesis and make generalization.

\section{Design Stage}

The design stage was conducted by designing a prototype of the developed learning media. Prototype design is done by arranging game to produce an initial design in the form of draft I and a game guide book. To get the initial design, the criterion test construction, media selection, and format selection are adjusted to the learning objectives. In outline, the game contained summary in the form of text and video; learning objectives; game rules; question exercises; animation of electrical conductivity test set; and electrical conductivity experiment video. To facilitate in making game, storyboard and flowchart are arranged first which would contain an overview of game to be created and developed. Electrolyte Fisher's game consists of three levels with two languages namely Indonesian and English. The components of problem-solving skill in the game were included in the question exercises at three levels.

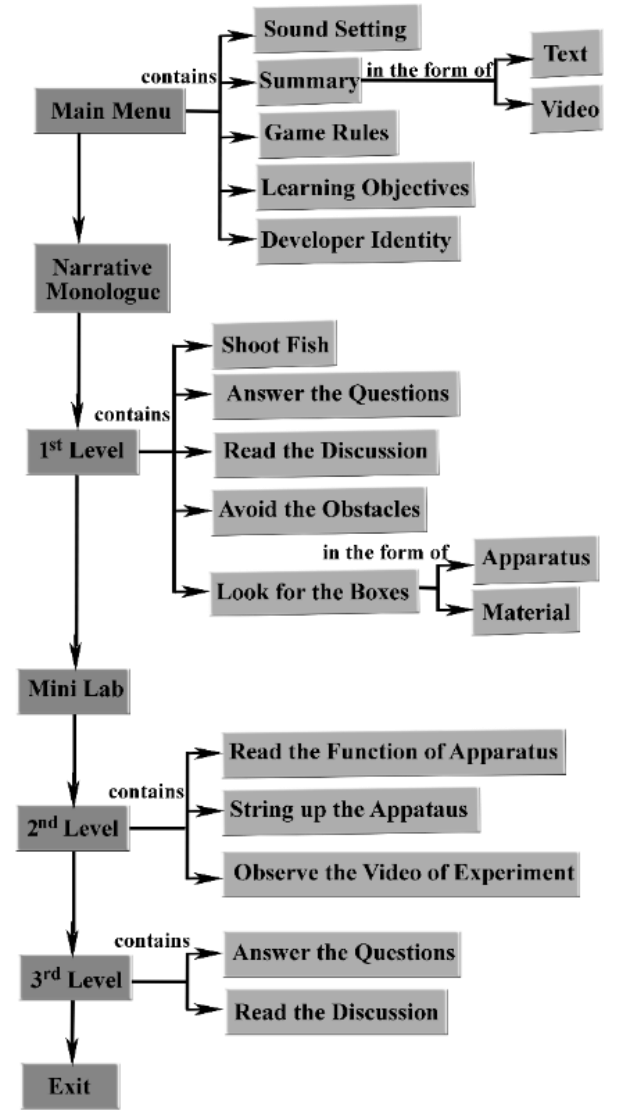

Figure 2. Overview of Electrolyte Fisher Game

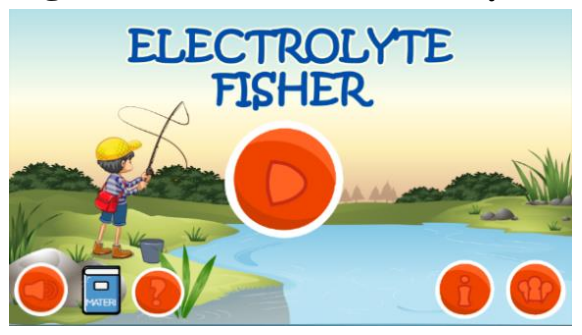

Figure 3. Homepage Layout

The game guide book was created to facilitate the use of the game intended for the chemistry teacher. In the book, there were several components, namely an overview of game; learning indicators and objectives; rules; how to operate game; and answer of questions in game. 

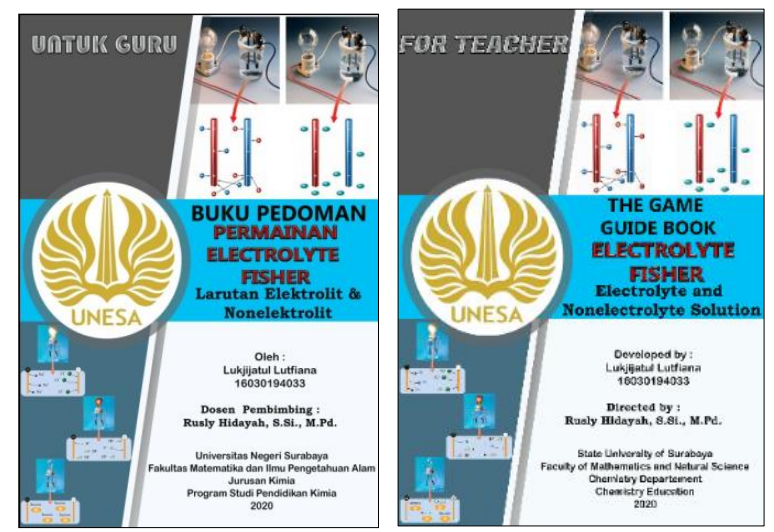

Figure 4. Cover of The Game Guide Book

\section{Develop Stage}

The aim of develop stage was to get the development product that has been improved according to the suggestion of reviewer and validated by validator. The step of the expert appraisal in this game included:

\section{a. Review Game}

The initial design of Electrolyte Fisher game to develop problem-solving skill (draft I) was reviewed by a chemistry lecturer. The reviewer gave suggestions for the improvement of the draft I by filling out review sheet.

\section{b. Revise Game}

The draft I of game was revised based on the results of review obtained from the chemistry lecturer in order to get better game results.

Table 3. Review of Game and Results of Revision

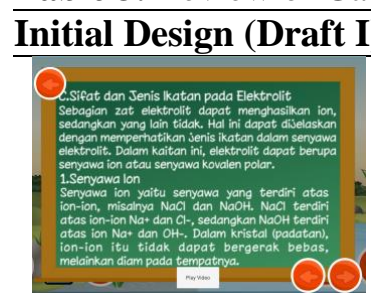

Writing ions of $\mathrm{Na}+$, $\mathrm{Cl}-, \mathrm{OH}-$

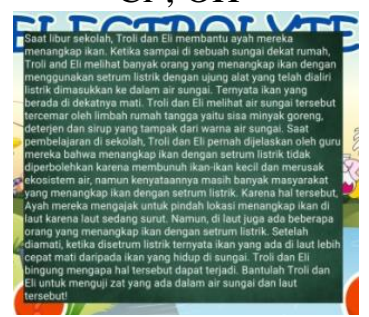

Text and voice of monologue were out of sync

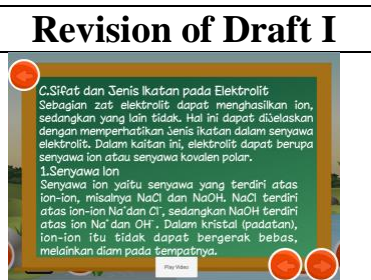
$\mathrm{Cl}^{-}, \mathrm{OH}^{-}$

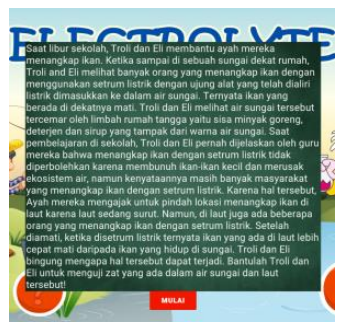

Text and voice of monologue were sync and there was login button
Writing ions of $\mathrm{Na}^{+}$,

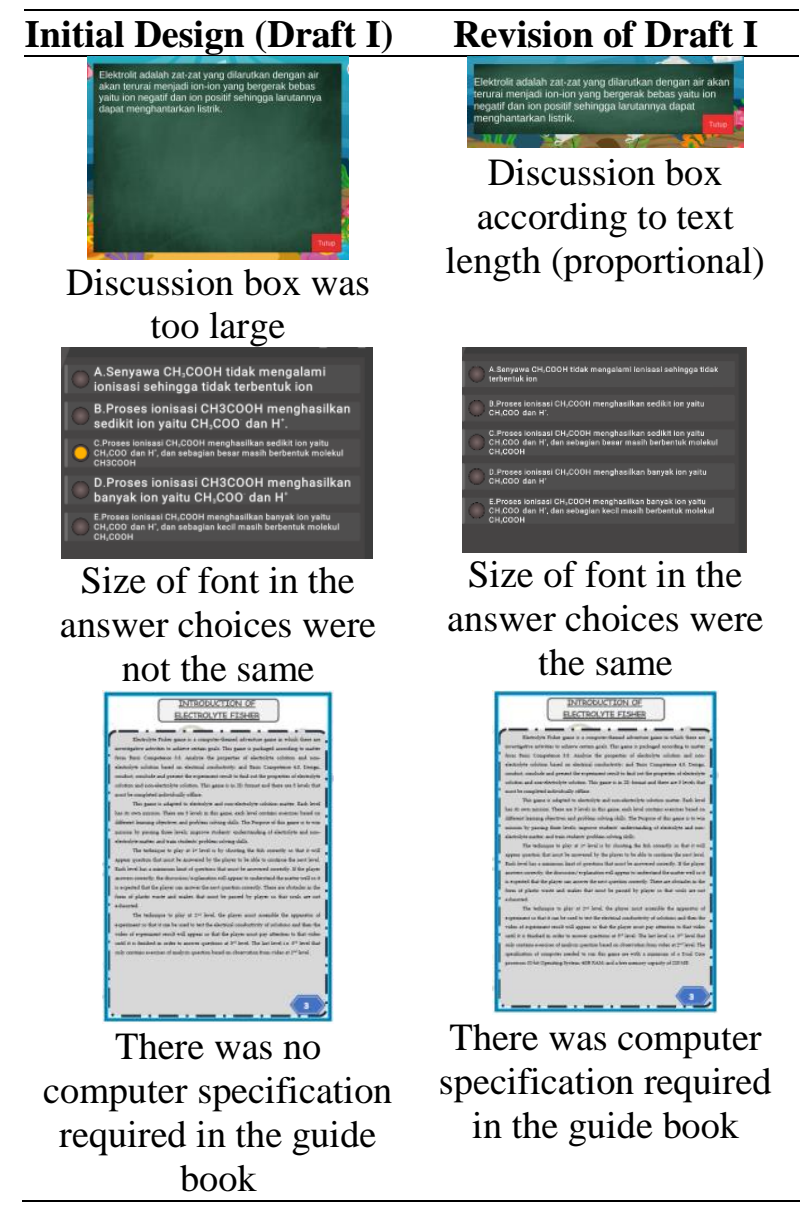

c. Validate game

The draft II was subsequently validated by three chemistry education experts namely two chemistry lecturers and one chemistry teacher to get a valid game to develop problem-solving skill [23]. It was expected that the problem-solving skill of student increased, it could also improve understanding concepts. Validators were asked to assess media in terms of content and construct by filling in assessments and suggestions on the validation sheet provided.

The content validity assessed consists of three aspects, namely the correctness of concept, the suitability of matter with learning objectives, and the suitability of game with problem-solving skill components. The construct validity was assessed as consisting of twelve aspects which included nine aspects of the suitability of learning media and three aspects of the suitability of display quality in game.

Table 4. Percentage of Content Validity

\begin{tabular}{cccc}
\hline Nu. & Aspects assessed & $\mathbf{P}(\%)$ & Category \\
\hline 1. & The truth of concept & 86.67 & Very Valid \\
2. & Having objectives & 86.67 & Very Valid \\
\hline
\end{tabular}




\begin{tabular}{cccc}
\hline Nu. & Aspects assessed & $\mathbf{P}(\%)$ & Category \\
\hline 3. & $\begin{array}{l}\text { The suitability with } \\
\text { problem-solving } \\
\text { skill components } \\
\begin{array}{c}\text { Average of content } \\
\text { validity percentage }\end{array}\end{array}$ & 80.00 & Valid \\
\hline
\end{tabular}

In Table 4, it could be seen that the content validity percentage of the Electrolyte Fisher game is $84.44 \%$ (very valid). This percentage proved that the Electrolyte Fisher game was valid in terms of chemical scientific principles. The aspect of concept truth got a percentage of $86.67 \%$ (very valid). This proved that matter, questions and discussions related to electrolyte and nonelectrolyte topics in the game were in accordance with the curriculum and chemical science. One of the criteria that had to be considered in determining learning media was that the media could support the subject content. The properties of subject matter were facts, principles, concepts, and generalizations, which became clearer so that students more easily mastered the matter [24]. Aspects of the suitability of matter with learning objectives obtained a percentage of $86.67 \%$ (very valid). This percentage proved that the matter contained in the game was appropriate with the learning objectives designed. One of the main components in the game is the goals to be achieved [25]. The learning media must have the suitability with learning objectives so that the media can help students to master the competencies expected [26].

The matter contained in the Electrolyte Fisher game in the form of two kinds, namely text, and video. Matter in the form of text containing a summary of matter accompanied by formula and table. While the matter in the form of video contained animations about the phenomenon of the problem that occur in daily life that aimed as help to direct students to be able to answer questions about the problem-solving component. Vygotsky explain that the learning occurs when students are in the zone of proximal development. In the zone of proximal development, students were given matter with a level of difficulty above their ability so that to help students reach the zone of proximal development, needed help that was done gradually
(Scaffolding) [22]. Through help in the form of video matter, it was hoped that students would be helped to understand concepts of matter gradually, and then at the end of the game, the students have been able to understand and answer the questions correctly. In the aspect of the suitability of game with problem-solving skill components obtained a percentage of $80.00 \%$, including valid category. This percentage proved that the elements contained in the game were appropriate for training four components in problem-solving skill. The game could improve problem-solving skill in learning natural science [27] [28]. The game can develop the other thinking skill namely critical thinking skill [29].

The first problem-solving skill component (identifying problems), and the second (formulating hypothesis) were in the form of questions at $1^{\text {st }}$ level. The third component was collecting and analyzing data. In collecting data, students had to assemble the experiment apparatus and observe the experimental video of electrical conductivity in solution at $2^{\text {nd }}$ level. Furthermore, at level 3 there were questions that contained observation tables that had to be completed. In analyzing data, students had to answer the analysis questions in accordance with table of observation at the third level. The fourth component, namely evaluating hypothesis and making generalizations, was presented in the questions at the third level. The question exercises in this game were in the form of multiple-choice questions with five answer choices, and accompanied by the discussion of the question if the students answered questions correctly.

Table 5. Percentage of Construct Validity

\begin{tabular}{clrc}
\hline Nu. & \multicolumn{1}{c}{ Aspects assessed } & $\mathbf{P}(\%)$ & Category \\
\hline 1. & $\begin{array}{l}\text { The properties of } \\
\text { natural science }\end{array}$ & 86.67 & Very Valid \\
2. & $\begin{array}{l}\text { The suitability with } \\
\text { students' character }\end{array}$ & 86.67 & Very Valid \\
3. & Having rules & 93.33 & Very Valid \\
4. & $\begin{array}{l}\text { Guiding } \\
\text { 5. }\end{array}$ & 93.33 & Very Valid \\
& $\begin{array}{l}\text { There were } \\
\text { competition, } \\
\text { requirements, and } \\
\text { strategies in playing } \\
\text { There was standard } \\
\text { of success }\end{array}$ & 93.00 & Valid \\
& & \\
\hline
\end{tabular}




\begin{tabular}{clcc}
\hline Nu. & Aspects assessed & $\mathbf{P}(\%)$ & Category \\
\hline $7 . \quad$ & $\begin{array}{l}\text { Challenging and } \\
\text { actively involving } \\
\text { students }\end{array}$ & 86.67 & Very Valid \\
8. $\quad \begin{array}{l}\text { Giving feedback } \\
\text { There were aspects } \\
\text { of decision-making }\end{array}$ & 83.33 & Very Valid \\
$\begin{array}{c}\text { Average of the suitability of } \\
\text { learning media percentage }\end{array}$ & 87.78 & Very valid \\
10. $\quad \begin{array}{l}\text { Display (colour, font } \\
\text { size, and animation) }\end{array}$ & 80.00 & Valid \\
11. $\quad \begin{array}{l}\text { Audio and visual } \\
\text { communication }\end{array}$ & 80.00 & Valid \\
12. $\quad \begin{array}{l}\text { Software } \\
\text { engineering }\end{array}$ & 88.89 & Very Valid \\
$\begin{array}{c}\text { Average of the suitability of } \\
\text { display quality percentage } \\
\text { Average of construct } \\
\text { validity percentage }\end{array}$ & 82.96 & Very valid \\
\hline
\end{tabular}

Table 5 showed that the construct validity percentage of the Electrolyte Fisher game was $85.37 \%$, which was categorized as very valid. This percentage proved that the Electrolyte Fisher game has been valid as a learning media as indicated by the percentage in Table 5 number 1 to 9. The display quality of the game was appropriate as indicated by the percentage in Table 5 number 10 to 12 . In the criteria of the suitability of learning media requirements got a percentage of $87.78 \%$ (very valid). There were 9 aspects assessed in this criterion. The aspect of the properties of natural science consisted of investigation and interrelationship in daily life. The aspect of the suitability of students' character in terms of learning styles and age so as to provide learning motivation for students. The aspect of having rules in the game was very valid so that it had good instructions and easy to understand. One of the main components in the game was rules [25]. The aspect of guiding in terms of the matter and rules in the game. The aspect of competition, requirement, and strategy in the form of the requirements to proceed to the next level that was increasingly difficult.

The aspect of success standard was the score acquisition for each level. The aspect of challenging and actively involving students in the form of different challenges at each level with time duration. The aspect of giving feedback in the form of gifts if they succeeded and punishment if they failed. One of the game advantages as a learning media was providing direct feedback so that it would enable the learning process to be more effective [25]. According to theory of behaviourism by Skinner namely operant conditioning explained that the pleasant consequences (reinforcement) and unpleasant consequences (punishment) could change a behaviour [22]. Based on the percentage result, the game has provided good feedback in the form of reinforcement and punishment. The aspect of decision-making in the form of the choice of answer questions and navigation direction. The theory of behaviourism by Thorndike explained that learning process often occurs through trial and error. The learning process by doing trial and error shows that success is formed while unsuccessful ones are ignored [22]. Students can direct navigation by doing trial error. The players as much as possible direct the navigation to the target in order to win the level and avoid obstacles so as not to fail. In the aspect of decision-making in a game, there are the choices for player to determine or choose or ensure activities that can be carried out [30].

The criteria of the suitability for display quality in the game got a percentage of $82.96 \%$ (very valid). This percentage proved that the appearance of the computer-based Electrolyte Fisher game could attract students to play it because it contained images, animations, \& sound that attracted attention. The development of computerized educational games can combine the quality of education and the technology of interactive games so as to make teaching chemistry process more interesting and effective for students which allows students to play and learn concept of matter at the same time [31]. Based on the percentage obtained in the content validity and construct validity, the computer-based Electrolyte Fisher game was declared valid to develop the problem-solving skill. The product or learning model was valid if it fulfilled the need aspect and newness aspect based on the strong empirical theory where there was consistency between the components achieved [23]. 


\section{CLOSING}

\section{Conclusion}

Based on data analysis and discussion, it was concluded that the Electrolyte Fisher game to develop students' problem-solving skill on electrolyte and nonelectrolyte solution topics could be declared valid. The validity of Electrolyte Fisher game in terms of content validity and construct validity was done by three validators. The computer-based Electrolyte Fisher game got a percentage of content validity and construct validity in the very valid category, namely the percentage of content validity was $84.44 \%$ and the construct validity was $85.37 \%$.

\section{Suggestion}

Research conducted only on the validity of computer-based Electrolyte Fisher game, so further research is needed so that this game can be applied in the actual classrooms. The developmental testing should be conducted to determine the practicality and effectiveness of the game in developing problem-solving skill. It aims to determine the feasibility of game as a learning media. In addition, students must really understand the rules of game when tested this game at the classroom because how to play and the rules of each level are different.

\section{REFERENCES}

1. Kemendikbud. 2016. Peraturan Menteri Pendidikan dan Kebudayaan Nomor 22 Tahun 2016 tentang Standar Proses Pendidikan Dasar dan Menengah. Jakarta: Kemendikbud.

2. Kemendikbud. 2018. Peraturan Menteri Pendidikan dan Kebudayaan No. 36 Tahun 2018 tentang Kerangka Dasar dan Struktur Kurikulum Sekolah Menengah Atas. Jakarta: Kemendikbud.

3. Irsyadi, R., Masykuri, M., \& Yamtinah, S. 2018. Upaya Peningkatan Kemampuan Memori dan Prestasi Belajar Siswa pada Materi Koloid dengan Model Pembelajaran Cooperative Integrated Reading and Composition (CIRC) Dilengkapi Media WebQuest pada Siswa Kelas XI IPA 2 Semester II SMA N 2 Boyolali. Jurnal
Pendidikan Kimia, vol. 7, no. 2, pp. 259-266, [Online]. Available: jurnal.uns.ac.id.

4. Herda, A., Damris. M., \& Asrial. 2014. Pengembangan Media Interaktif pada Pembelajaran Larutan Elektrolit dan Non Elektrolit untuk Siswa SMA Kelas X. EduSains, vol. 3, no. 1, pp. 22-27, [Online]. Available: online-journal.unja.ac.id.

5. Krisyanti, P. E. D., \& Sanjaya, I. G. M. 2014. Pengembangan Media Pembelajaran E-book Interaktif Berorientasi Pendidikan Karakter pada Materi Larutan Elektrolit dan Non Elektrolit. Journal of Chemical Education, vol. 3, no. 3, pp. 148-152, [Online]. Available: jurnalmahasiswa.unesa.ac.id.

6. Simehatte, I., Zulfadli, \& Nazar, M. 2016. Pengembangan Media Eleksido Menggunakan Camtasia Studio 8 Pada Larutan Elektrolit Dan Nonelektrolit Untuk Siswa Kelas X MIA SMA N 1 Krueng Barona Jaya. Jurnal Ilmiah Mahasiswa Pendidikan Kimia, vol. 1, no. 3, pp. 27-34, [Online]. Available: www.jim.unsyiah.ac.id.

7. Sunyono. 2017. Model Pembelajaran Kimia Berbasis Lingkungan dan Keterampilan Generik; Solusi Alternatif dalam Memecahkan Masalah Pembelajaran Kimia. Yogyakarta: Innosain.

8. Dahar, R. W. 2011. Teori-teori Belajar \& Pembelajaran. Jakarta: Erlangga.

9. Kemendikbud. 2014. Peraturan Menteri Pendidikan dan Kebudayaan Republik Indonesia Nomor 61 Tahun 2014 tentang Kurikulum Tingkat Satuan Pendidikan pada Pendidikan Dasar dan Pendidikan Menengah. Jakarta: Kemendikbud.

10. Nasir, M., Madlazim, \& Sanjaya, I. G. M. 2016. Studi Pendahuluan Keterampilan Pemecahan Masalah dan Metakognisi Siswa SMA Berbasis UAPAC+SE. Prisma Sains : Jurnal Pengkajian Ilmu dan Pembelajaran Matatematika dan IPA IKIP Mataram, vol. 4, no. 1, p. 13.

11. Eggen, P., \& Kauchak, D. 2012. Strategi dan Model Pembelajaran: Mengajarkan Konten dan Keterampilan Berpikir. Jakarta: Indeks.

12. Sanjaya, W. 2008. Perencanaan dan Desain Sistem Pembelajaran. Jakarta: Kencana Perdana Media Grup.

13. Rastegarpour, H., \& Marashi, P. 2012. The 
Effect of Card Games and Computer Games on Learning of Chemistry Concepts. Procedia - Social and Behavioral Sciences, vol. 31, no. 2011, pp. 597-601.

14. Santoso, Y. R. D., \& Purnomo, J. T. 2017. Hubungan Kecanduan Game Online terhadap Penyesuaian Sosial pada Remaja. Jurnal Humaniora Yayasan Bina Darma, vol. 4, no. 1, pp. 27-44, [Online]. Available: www.jurnalilmiah-paxhumana.org.

15. Anggraeni, D., \& Lutfi, A. 2016. Pengembangan Permainan The Tomb Labs Raider sebagai Media Pembelajaran pada Materi Larutan Elektrolit dan Non Elektrolit. UNESA Journal of Chemical Education, vol. 5, no. 2, pp. 533-451, [Online]. Available: jurnalmahasiswa.unesa.ac.id.

16. Rahmawati, A., \& Lutfi, A. 2018. The Development of Super Chem Game Oriented Android as Instructional Media Electrolyte and Non Electrolyte. Journal Chemistry Education Research, vol. 2, no. 1, pp. 1-10, [Online]. Available: journal.unesa.ac.id.

17. Cheng, M., Chen, J., Chu, S., \& Chen, S. 2015. The Use of Serious Games in Science Education: A Review of Selected Empirical Research from 2002 to 2013. Journal of Computers Education, vol. 2, no. 3, pp. 353375.

18. Liu, C. C., Cheng, Y. B., \& Huang, C. W. 2011. The Effect of Simulation Games on The Learning of Computational Problem Solving. Computers and Education, vol. 57, no. 3, pp. 1907-1918.

19. Thiagarajan, S., Semmel, D. S., \& Semmel, M. I. 1974. Instructional Development for Training Teachers of Exceptional Children: A Sourcebook. Minneapolis: Leadership Training Institute, University of Minnesota.

20. Akker, J. van den, Bannan, B., Kelly, A. E., Nieveen, N., \& Plomp T. 2013. Educational Design Research. Enschede: Netherlands Institute for Curriculum Development (SLO).

21. Riduwan. 2016. Skala Pengukuran dan Variabel-Variabel Penelitian. Bandung: Alfabeta.

22. Salvin, R. E. 2009. Educational Psychology: Theory and Practice. New Jersey: Pearson Education Inc.

23. Pandiangan, P., Sanjaya, I. G. M., \& Jatmiko,
B. 2017. The Validity and Effectiveness of Physics Independent Learning Model to Improve Physics Problem Solving and Selfdirected Learning Skills of Students in Open and Distance Education Systems. Journal of Baltic Science Education, vol. 16, no. 5, pp. 651-665.

24. Sudjana, N., \& Rivai, A. 2009. Media Pengajaran. Bandung: Sinar Baru Algensindo.

25. Sadiman, A. S., Rahardjo, R., Haryono, A., \& Harjito. 2014. Media Pendidikan: Pengertian, Pengembangan, dan Pemanfaatannya. Jakarta: Raja Grafindo Persada.

26. Prastowo, A. 2015. Panduan Kreatif Membuat Bahan Ajar Inovatif. Yogyakarta: Diva Press.

27. Kirana, G. C., Ambarwati, R., \& Martini. 2014. Pengembangan Permainan Edukatif Wonderful Step sebagai Media dalam Pembelajaran IPA Materi Pemanasan Global Di SMP untuk Melatihkan Keterampilan Memecahkan Masalah. Jurnal Mahasiswa Unesa, pp. 1-8, [Online]. Available: jurnalmahasiswa.unesa.ac.id.

28. Pitrianingsih, L. 2019. Validitas Permainan Gobak Sodor untuk Melatihkan Keterampilan Memecahkan Masalah pada Materi Pemanasan Global. Jurnal E-Pensa, vol. 7, no. 2, pp. 81-85, [Online]. Available: jurnalmahasiswa.unesa.ac.id.

29. Hidayah, R., \& Isma, E. N. 2015. Pengembangan Media Permainan Kartu Domichem pada Materi Termokimia dengan Pendekatan Konstruktivis untuk Melatihkan Keterampilan Berpikir Kritis. Molluca Journal of Chemistry Education, vol. 5, no. 2, pp. 12-16.

30. Fenrich, P. 1997. Practical Guidelines for Creating Instructional Multimedia Applications. Fort Worth: Harcourt Brace College Publishers.

31. Junior, J. N. D. S., Nobre, D. J., Nascimento, R. S. D., Torres, G. S., Leite, A. J. M., Monteiro, A. J., Alexandre, F. S. O., Rodríguez, M. T., \& Rojo, M. J. 2018. Interactive Computer Game that Engages Students in Reviewing Organic Compound Nomenclature. Journal of Chemical Education, vol. 95, no. 5, pp. 899-902. 